\title{
Life Cycle Assessment of Biochar versus Metal Catalysts Used in Syngas Cleaning
}

\author{
Robert S. Frazier *, Enze Jin and Ajay Kumar \\ Biosystems and Agricultural Engineering, Oklahoma State University, $212 \mathrm{Ag}$ Hall, Stillwater, \\ OK 74074, USA; E-Mails: enze@okstate.edu (E.J.); ajay.kumar@ okstate.edu (A.K.) \\ * Author to whom correspondence should be addressed; E-Mail: robert.frazier@ okstate.edu; \\ Tel./Fax: +1-405-744-5289.
}

Academic Editor: Shusheng Pang

Received: 24 September 2014 / Accepted: 10 December 2014 / Published: 15 January 2015

\begin{abstract}
Biomass gasification has the potential to produce renewable fuels, chemicals and power at large utility scale facilities. In these plants catalysts would likely be used to reform and clean the generated biomass syngas. Traditional catalysts are made from transition metals, while catalysts made from biochar are being studied. A life cycle assessment (LCA) study was performed to analyze the sustainability, via impact assessments, of producing a metal catalyst versus a dedicated biochar catalyst. The LCA results indicate that biochar has a $93 \%$ reduction in greenhouse gas (GHG) emissions and requires $95.7 \%$ less energy than the metal catalyst to produce. The study also estimated that biochar production would also have fewer impacts on human health (e.g., carcinogens and respiratory impacts) than the production of a metal catalyst. The possible disadvantage of biochar production in the ecosystem quality is due mostly to its impacts on agricultural land occupation. Sensitivity analysis was carried out to assess environmental impacts of variability in the two production systems. In the metal catalyst manufacture, the extraction and production of nickel $(\mathrm{Ni})$ had significant negative effects on the environmental impacts. For biochar production, low moisture content (MC, 9\%) and high yield type (8 tons/acre) switchgrass appeared more sustainable.
\end{abstract}

Keywords: biochar; syngas; catalyst; gasification; tar; life cycle assessment (LCA); impacts; sustainability 


\section{Introduction}

Biomass can be converted into solid, liquid and gaseous fuel products through either biological or various thermochemical processes [1,2]. One of the technologies that utilize biomass is gasification, a thermochemical process [3]. This process has gathered renewed interest because it is typically more efficient than other thermochemical processes and has potential to be commercially feasible in near-term for energy and fuels production [4]. This greater efficiency also translates into lower emissions per mega joule of energy produced. Studies indicate an integrated biomass gasification combined cycle (IGCC) electrical power production plant with $\mathrm{CO}_{2}$ removal could mitigate $\mathrm{CO}_{2}$ emissions by $76 \%-79 \%$ compared to a conventional coal IGCC power plant [5].

Life cycle assessment (LCA) can be used to the show impact differences between processes. For example, a LCA study concluded that hydrogen production through biomass gasification for electricity production for subsequent used in electrolysis system had $86 \%$ reduction in greenhouse gas (GHG) emissions, although it also had greater acidification impacts than hydrogen production through biomass gasification and subsequent steam reforming system [6]. This benefit and detriment identified for each process are results of LCA studies. These results suggest that advantages in one impact area (GHG) may be partially offset by damages (acidification) in other areas.

Biomass gasification produces syngas that must cleaned before it can utilized for fuels and power production. The traditional methods of hot syngas cleaning include filtration, water scrubbing, thermal cracking and catalytic cracking [7]. The current preferred methods for reducing syngas tars is by using solvents (acetone and water) or catalysts (e.g., nickel-alumina catalyst) the later converting the tars to more useful gases. The solvent processes avoid using higher temperatures $\left(>700{ }^{\circ} \mathrm{C}\right)$ and associated additional energy [8], however, they create a waste disposal issue. Catalyst-based tar removal methods can crack and reform tar compounds to produce extra gases such as carbon monoxide and hydrogen which are the main syngas components. Essentially, the catalysts make the syngas production process more efficient. The typical catalysts used in cleaning syngas process are nickel $\left(\mathrm{Ni}\right.$ ) catalysts with the most common being $\mathrm{Ni} / \mathrm{Al}_{2} \mathrm{O}_{3}$ and $\mathrm{Ni} / \mathrm{CeO}_{2} / \mathrm{Al}_{2} \mathrm{O}_{3}[9]$.

From an overall environmental standpoint, use of these transition metals as syngas catalysts could negatively impact the overall sustainability of the final syngas biofuel due to extraction, processing and disposal of the metals. Recent research has shown the potential for biochar to be used as a syngas catalyst with possible environmental benefits [10].

The research involving LCA of biochar generated by gasification is limited and no study has been found conducting a comparative LCA of biochar and metal catalyst used in the syngas tar removal process. Because significant quantities of catalyst would likely be employed in utility-scale gasification plants, knowledge of the two catalyst's environmental impacts is important and the reason this comparative LCA was undertaken.

\subsection{Life Cycle Assessment of Biochar Production and Use}

Besides its novel use as a syngas cleaning catalyst, biochar, usually a byproduct of biomass gasification or pyrolysis, has many potential uses with one being use as a soil amendment, and it is sometimes produced primarily for this task [11]. In this capacity, the material holds promise to help 
mitigate climate change levels by sequestering and distributing carbon back into the soil [12]. The utilization of biochar as a substitute for fertilizer and as a source of heat, bio-oil and catalyst for gases for farm and ranch use also holds promise for agricultural applications [13]. Selected LCA studies on biochar are shown below.

There have been several LCA studies involving biochar that show both positive and negative environmental effects of using the material. An LCA study on the energetic and climate change performance of biochar produced by pyrolysis of switchgrass with two different land-use scenarios showed that if energy crops such as switchgrass are planted on land converted from annual food crops, the indirect land-use change impacts may lead to more GHG emissions than GHG sequestration. The article concluded was that it may not be appropriate to replace food crops with fuel biomass crops such as switchgrass on the same land [14].

In another study, a LCA of biochar co-firing with coal for electricity generation in Taiwan was conducted [15]. When compared to a $100 \%$ coal-fired system, the biochar co-firing with co-firing ratios of $10 \%$ and $20 \%$ (biochar to coal) had benefits in five environmental impact categories, including aquatic eco toxicity, terrestrial eco toxicity, land occupation, global warming, and non-renewable energy [15]. For evaluating the environmental impact of biochar as a soil amendment, an LCA of biochar implementation in agriculture in Zambia was conducted. The results confirmed that the use of biochar in farming was beneficial for soil condition, climate change and fossil fuel consumption but on the negative side, also had a possible increase in air borne (PM2.5, PM10 — respiratory distress) particles [16].

\subsection{Variability and Uncertainty in Life Cycle Assessment Studies}

Uncertainty is defined as the error of the outcome caused by variability or deficient data in the model input [17]. LCAs are very dependent on the data quality and sensitive to data variability because the quality of an LCA is directly related to the inventory upon which it is based [18]. Although practitioners have been long aware of improving the data quality, the validity and uncertainty of final LCA reports still exist and cannot be totally eliminated due to the inherent variations in the inventory data [19]. Many articles note that the data uncertainty is caused by a general lack of accurate data values and incorrect measurement techniques during the life cycle inventory (LCI) phase of the study [20]. This situation is especially prevalent in natural or agricultural systems such as biomass production where the amount of precipitation, crop yields and other critical inputs are essentially random in nature.

The variability in LCA is typically addressed by applying sensitivity analysis. This ensures that the LCA results are more useful by showing the effects of input variation, including more possible scenarios, choosing more precise data collection, and explicitly demonstrating assumptions used [21].

The objective of this LCA was to assess the sustainability of biochar versus metal catalysts in the production of syngas for utility-scale fuels and power. The study assumes that biochar (catalyst) and syngas are the two major co-products of the gasification process (biochar is not considered a waste). This assumption is conservative but could reflect large scale biochar production as a dedicated catalyst. The LCA is performed considering the cycles of the production of raw material production to the final catalyst for both metal and biochar. The analysis was conducted using the SimaPro 7.3.3 ${ }^{\circledR}$ Software (Pre' North America Inc., Washington, DC, USA) to assess the environmental impacts. A sensitivity 
analysis was carried out to identify the factors with the most expected environmental impacts in each catalyst production system and how the results change by variations in identified catalyst production input parameters.

\section{Methodology}

The main starting components of the LCA, which are the "functional unit" and system boundary are discussed. The general model data sources (inventories) and output scoring are also examined below.

\subsection{Functional Unit}

The functional unit is a basic LCA standard component and one was determined for the comparison of the two catalysts in question. The functional unit is often a "task" versus a material as is the case here. The industrial amount of feedstock on a dry basis needed for utility-scale power plant biochar production was assumed to be 2000 metric tons per day [22]. The syngas yield was $2 \mathrm{~m}^{3} / \mathrm{kg}$ of dry biomass and the amount of tar to be removed was $4.28 \mathrm{~g} / \mathrm{m}^{3}$ of syngas. The functional unit was determined to be the amount of catalyst needed to condition the syngas based on an average gas production of 4,000,000 $\mathrm{m}^{3} /$ day. The amounts of catalysts used for cleaning the same quantity of syngas are different due to the difference in tar removal efficiencies of two catalysts (metal versus biochar) [23]. At $800{ }^{\circ} \mathrm{C}$ syngas cleaning temperature, mean toluene (a model tar) removal efficiencies of biochar and $\mathrm{Ni}$ catalysts were found to be $80.75 \%$ and $97.70 \%$, respectively [23]. Amount of biochar used was twice the amount of Ni catalyst. The efficiencies may change with change in reaction conditions but this was the best efficiency reported and used in this study. Regeneration of the catalysts was not examined in this study. Based on reported performance of the two catalysts, $396 \mathrm{~kg} / \mathrm{day}$ of metal catalysts or $952 \mathrm{~kg} /$ day of biochar catalyst were needed.

\subsection{System Boundaries}

Another fundamental component of the LCA study is the system boundary for each product or process being compared. For the metal catalyst, the system boundary included all necessary production processes up to the point of use in the gasifier. The processes of producing raw metals for the metal catalyst included mining, crushing and transportation of ores. The raw materials such as nickel ore and bauxite are the main inputs of industrial metal catalyst manufacture along with various materials such as: air, water, chemicals and energy sources. The simplified process flow of the metal catalyst production is given in Figure 1. As biochar is assumed to be one of the two main products of the gasification for this study, the LCA scope only includes the fraction (10\% based on biochar yield) of energy and materials needed for syngas production. Biochar is collected typically in particle cyclones from the syngas downstream of the gasifier. The simplified process flow of the biochar catalyst is given in Figure 2 below. 


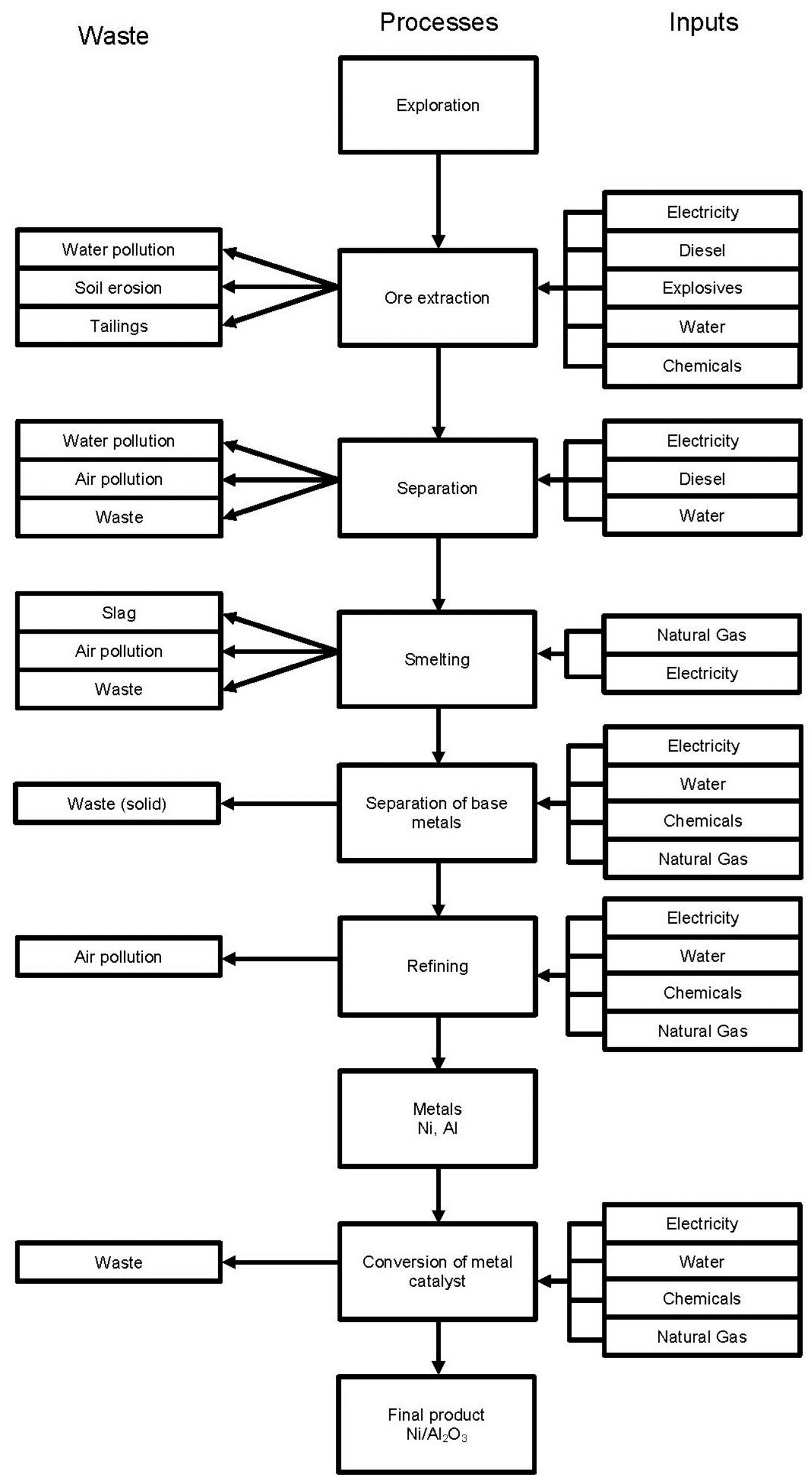

Figure 1. Simplified system boundary for metal catalyst production. 
Waste

Processes

Inputs

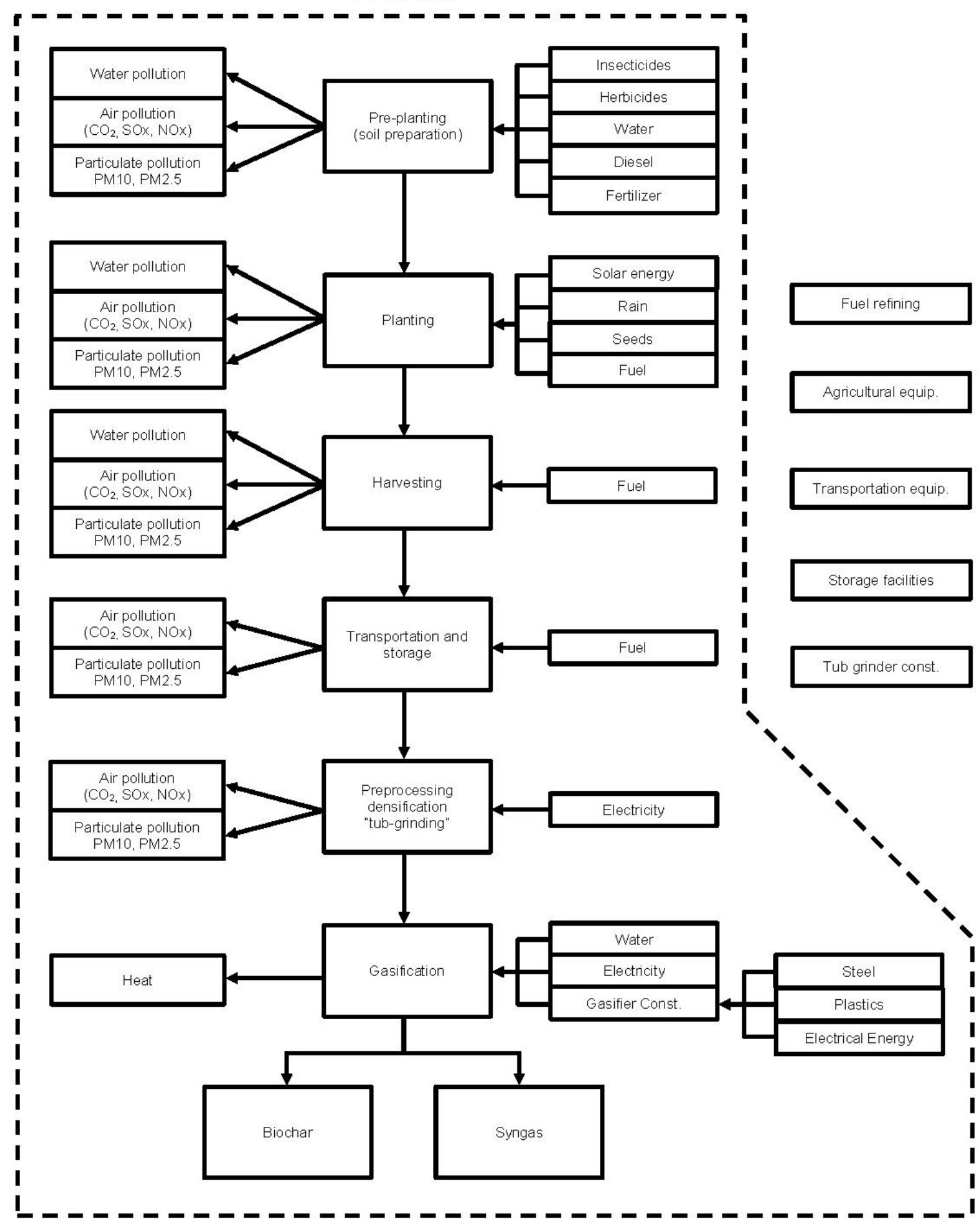

Figure 2. Simplified system boundaries (inside dotted line) for biochar production.

\subsection{Assumptions}

Assumptions are another important aspect for an LCA study since they have a strong influence on results, model manageability, and make the assessment as transparent as possible. Sensitivity analysis was used to test the importance of some assumptions. Below is a list of assumptions used in this comparative LCA. As previously mentioned, the boundary for the studied systems was for the production of the catalysts only and a $0.5 \%$ cutoff was used in SimaPro ${ }^{\circledR}$ for the database inventory. 
Biochar was considered for catalyst use only-no soil supplementation or other uses. Hifuel-110 ${ }^{\circledR}$ (Johnson Matthey, Catalysis and Chiral Technologies, West Deptford, NJ, USA) was used as an analog for $\mathrm{NiO} / \mathrm{Al}_{2} \mathrm{O}_{3}$ catalyst in the cleaning syngas experiment. The biochar yield of gasification was $10 \%$ of the switchgrass input [24]. The mass of materials used in the gasifier construction per volume of syngas was a linear scale-up to a utility scale gasification power plant. No stochastic behavior for the processes was modeled in this study. At the utility scale, we assumed an operation of 10 years and 220 day/year which is based on an operation efficiency of 60\% [25]. The switchgrass land is used for 10 years with two harvests per year. The yield of switchgrass, a national (US) average, was obtained from the National Renewable Energy Laboratory Department of Energy (NREL, Golden, CO, USA) [26]. The database of switchgrass production does not include use of pesticides. The disposal phases of both catalysts' life cycle were not considered. The mass ratio of nickel oxide (NiO) to aluminum oxide $\left(\mathrm{Al}_{2} \mathrm{O}_{3}\right)$ in the metal catalyst mixing process was 1 to 9 .

\subsection{Assessment Tool and Method}

The SimaPro ${ }^{\circledR}$ LCA software was used to develop the model and compare production of the two catalysts. Life cycle impact assessment (LCIA) is an output of LCA and is an evaluation of the potential environmental impacts during a product's life time. The impact assessment was performed with the IMPACT 2002+ (within the SimaPro ${ }^{\circledR}$ Software) method which includes midpoint and endpoint analysis in this study. A framework of the method is shown in Figure 3. A midpoint (category) indicator is the characterization of the elementary flows and environmental interactions and impacts [27]. Midpoints are considered to be links in the cause-effect chain (environmental mechanism) of an impact category, prior to the endpoints (damage impact), at which characterization factors or indicators can be calculated to indicate the relative importance of emissions or extractions in a LCI [28].

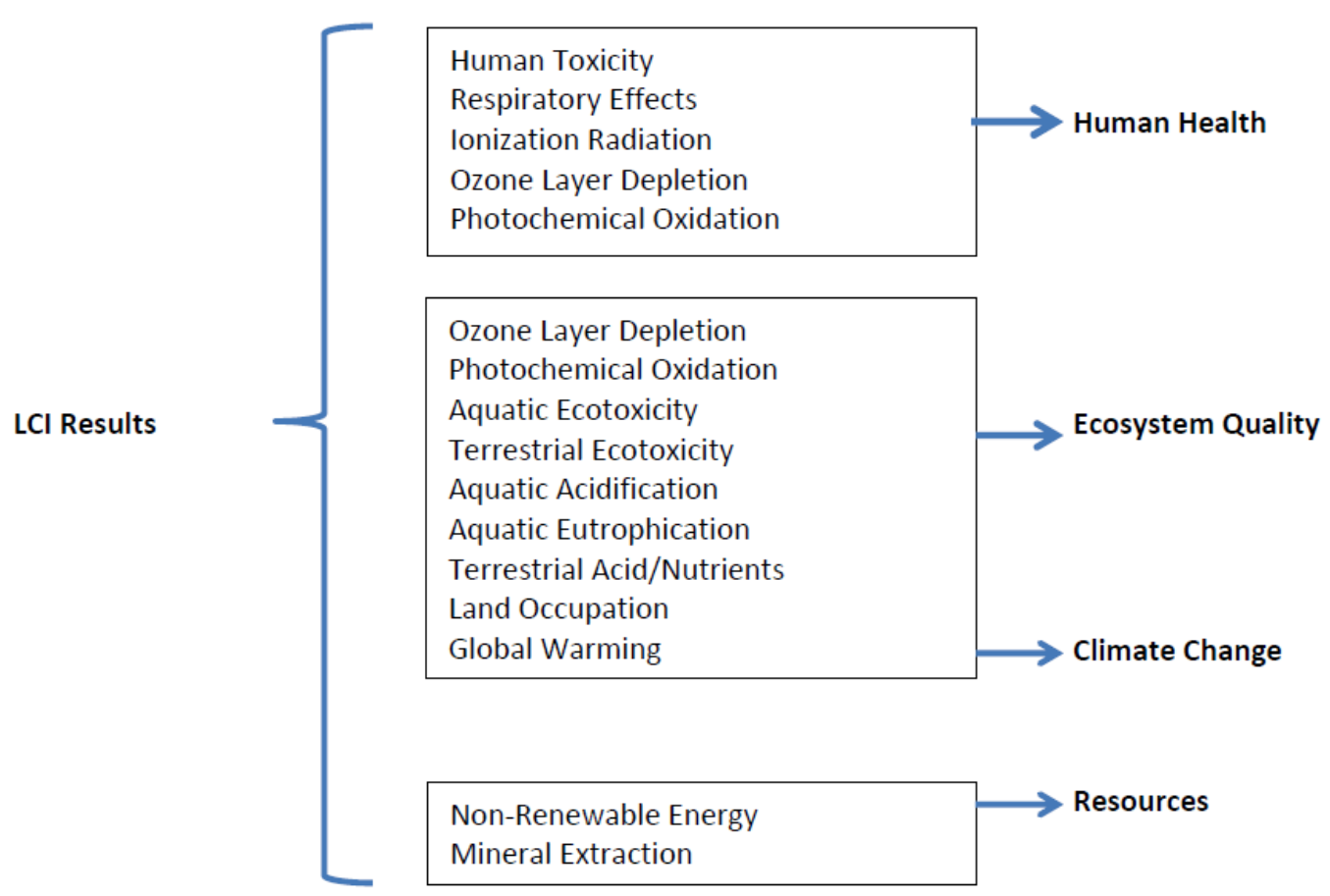

Figure 3. Overall scheme of the IMPACT 2002+ framework [27]. LCI: life cycle inventory. 
The LCIA methodology used classical impact assessment methods to group the similar LCA results into midpoint categories such as climate change and eco-toxicity (Figure 2). A score of one midpoint characterization factor was given in equivalents of a substance compared to a reference substance (e.g., $\mathrm{CO}_{2}$ for $\mathrm{GHG}, \mathrm{C}_{2} \mathrm{H}_{3} \mathrm{Cl}$ for toxicity, etc.). Then damage oriented methods modeled the cause-effect chain out to the damage categories such as climate change or human health [27]. Within two different product systems, a comparison of impacts was generated to determine which system is possibly more sustainable.

\subsection{Life Cycle Inventory}

The full inventory database was obtained from the SimaPro ${ }^{\circledR}$ 7.3.3 Software and applicable to most European and American processes. Most specific data for the gasification process were obtained from Sharma et al. [29]. The remaining data were collected from published databases and academic literature and cited accordingly.

\subsection{Metal Catalyst Inventory}

Data for the NiO material were obtained from the Nickel Institute LCI Report [30]. All inputs and outputs of $1 \mathrm{~kg} \mathrm{Ni}$ included in $\mathrm{NiO}(77 \mathrm{Ni} w t \%)$ are integrated in Table 1 and scaled up to the functional unit when modeling the final catalyst. The inventory data for $\mathrm{Al}_{2} \mathrm{O}_{3}$, which is the base support material, is obtained directly from the US-EI 2.2 Database [31] that is available in the SimaPro ${ }^{\circledR}$ LCA Libraries.

The final metal catalyst consists of $10 \mathrm{wt} \% \mathrm{NiO}$ and $90 \mathrm{wt} \% \mathrm{Al}_{2} \mathrm{O}_{3}$. The nitrate solutions with nickel and aluminum ions are filtered and heated at $105^{\circ} \mathrm{C}$ in air to dry [32]. Subsequently the catalyst samples are mixed by mechanical mixer into powders and heat treated at $700{ }^{\circ} \mathrm{C}$. Using standard heat transfer equations and a quantity of $1 \mathrm{~kg}$ of $\mathrm{Ni} / \mathrm{Al}_{2} \mathrm{O}_{3}$, the energy for thermally drying and treating the metal catalyst is calculated at approximately $0.5 \mathrm{MJ} / \mathrm{kg}$.

Table 1. Inventory data for nickel oxide $(\mathrm{NiO})$ production (1 $\mathrm{kg}$ of nickel $(\mathrm{Ni})$ in $\mathrm{NiO})$ [30]. Reprinted/Reproduced with permission from Nickel Institute, 2015.

\begin{tabular}{ccc}
\hline Category & Unit process & Quantity \\
\hline & Coal, in ground & $3.1 \mathrm{~kg}$ \\
& Iron $(\mathrm{Fe}$, ore $)$ & $7.4 \times 10^{-4} \mathrm{~kg}$ \\
Resource (input) & Limestone $\left(\mathrm{CaCO}_{3}\right)$ & $0.4 \mathrm{~kg}$ \\
& Natural gas, in ground & $3.5 \mathrm{~kg}$ \\
& $\mathrm{Ni}$, in ground & $2.5 \mathrm{~kg}$ \\
& Oil, in ground & $4.5 \mathrm{~kg}$ \\
& Uranium (U, ore) & $2.5 \times 10^{-5} \mathrm{~kg}$ \\
Technosphere (input) & Total water used & $309 \mathrm{~L}$ \\
\hline & Total primary energy & $455 \mathrm{MJ}$ \\
\hline \multirow{2}{*}{ Emission to air (output) } & Carbon dioxide & $26,337 \mathrm{~g}$ \\
& Carbon monoxide & $62 \mathrm{~g}$ \\
& Nitrogen oxides, $\mathrm{NO}_{2}$ & $85 \mathrm{~g}$ \\
& Nitrous oxide & $2.0 \mathrm{~g}$ \\
\hline
\end{tabular}


Table 1. Cont.

\begin{tabular}{|c|c|c|}
\hline Category & Unit process & Quantity \\
\hline \multirow{24}{*}{ Emission to air (output) } & Particulates & $74 \mathrm{~g}$ \\
\hline & Sulfur oxides, $\mathrm{SO}_{2}$ & $2,205 \mathrm{~g}$ \\
\hline & Methane & $47 \mathrm{~g}$ \\
\hline & Hydrocarbons & $22 \mathrm{~g}$ \\
\hline & $\mathrm{Ni}$ & $6.1 \mathrm{~g}$ \\
\hline & Chromium & $3.3 \times 10^{-3} \mathrm{~g}$ \\
\hline & Arsenic & $1.0 \mathrm{~g}$ \\
\hline & Copper & $1.2 \mathrm{~g}$ \\
\hline & Cobalt & $5.6 \times 10^{-2} \mathrm{~g}$ \\
\hline & Zinc & $0.19 \mathrm{~g}$ \\
\hline & Lead & $0.53 \mathrm{~g}$ \\
\hline & Cadmium & $3.7 \times 10^{-3} \mathrm{~g}$ \\
\hline & Mercury & $3.6 \times 10^{-2} \mathrm{~g}$ \\
\hline & Silver & $1.1 \mathrm{~g}$ \\
\hline & Metals & $0.23 \mathrm{~g}$ \\
\hline & Ammonia & $4.7 \mathrm{~g}$ \\
\hline & Chloride & $1.3 \times 10^{-3} \mathrm{~g}$ \\
\hline & Dioxins & $4.4 \times 10^{-7} \mathrm{~g}$ \\
\hline & Volatile organic compounds & $2.7 \mathrm{~g}$ \\
\hline & Hydrogen chloride & $0.98 \mathrm{~g}$ \\
\hline & Hydrogen cyanide & $3.9 \times 10^{-5} \mathrm{~g}$ \\
\hline & Hydrogen fluoride & $5.9 \times 10^{-2} \mathrm{~g}$ \\
\hline & Hydrogen sulfide & $4.6 \times 10^{-2} \mathrm{~g}$ \\
\hline & Sulfuric acid & $40 \mathrm{~g}$ \\
\hline \multirow{16}{*}{ Emission to water (output) } & Biochemical oxygen demand & $1.1 \mathrm{~g}$ \\
\hline & Chemical oxygen demand & $8.7 \mathrm{~g}$ \\
\hline & Sulfates & $186 \mathrm{~g}$ \\
\hline & Nitrogenous matter, as $\mathrm{N}$ & $269 \mathrm{~g}$ \\
\hline & Phosphates, as $\mathrm{P}$ & $9.9 \times 10^{-3} \mathrm{~g}$ \\
\hline & Total organic compounds & $0.43 \mathrm{~g}$ \\
\hline & Arsenic & $6.0 \times 10^{-4} \mathrm{~g}$ \\
\hline & $\mathrm{Ni}$ & $0.14 \mathrm{~g}$ \\
\hline & Copper & $8.7 \times 10^{-3} \mathrm{~g}$ \\
\hline & Zinc & $1.3 \times 10^{-3} \mathrm{~g}$ \\
\hline & Lead & $4.1 \times 10^{-2} \mathrm{~g}$ \\
\hline & Mercury & $4.0 \times 10^{-5} \mathrm{~g}$ \\
\hline & Silver & $1.8 \times 10^{-4} \mathrm{~g}$ \\
\hline & Cadmium & $4.2 \times 10^{-5} \mathrm{~g}$ \\
\hline & Chromium & $3.3 \times 10^{-4} \mathrm{~g}$ \\
\hline & Acids & $1.4 \times 10^{-2} \mathrm{~g}$ \\
\hline \multirow{3}{*}{ Emission to soil (output) } & Waste rock and backfill & $175 \mathrm{~kg}$ \\
\hline & Tailing and other process residues & $187 \mathrm{~kg}$ \\
\hline & Other solid materials & $1.8 \mathrm{~kg}$ \\
\hline
\end{tabular}




\subsection{Biochar Catalyst Inventory}

The LCI data for the biomass feed material (switchgrass) was obtained from the NREL report [26] that includes soil preparation, planting, harvesting, storage, transportation and pretreating. The land use is based on an estimate of 10 years of life considering an average switchgrass yield of 14,800 kg/ha [26]. The detailed data of the switchgrass production is shown in Table 2. The metal used to construct the gasifier included steel pipes and steel plates. Inputs of constructing the gasifier was based on materials reported in a LCA of a gasification 407.1 MW power plant [33] with $42 \%$ efficiency [25]. Finally, the material masses of construction materials for a large gasifier for this case are 6099 tons of steel, 6099 tons of cement and 36,660 tons of aggregates.

Table 2. Inventory data for 1 ton switchgrass feedstock production [26]. Reprinted/Reproduced with permission from National Renewable Energy Laboratory (NREL), 2014.

\begin{tabular}{ccc}
\hline Category & Unit process & Quantity \\
\hline Carbon dioxide & $1.5 \times 10^{3} \mathrm{~kg}$ \\
Resource (input) & Energy, from biomass & $1.5 \times 10^{4} \mathrm{MJ}$ \\
& Occupation, pasture and meadow & $0.68 \mathrm{ha}$ \\
& Transformation from permanent crop & $2.25 \times 10^{-2} \mathrm{ha}$ \\
Transformation from pasture and meadow & $2.25 \times 10^{-2} \mathrm{ha}$ \\
& Transformation from arable & $2.25 \times 10^{-2} \mathrm{ha}$ \\
\hline Tillage, rotary cultivator and rolling & $6.8 \times 10^{-3} \mathrm{ha}$ \\
& Fertilizer & $0.068 \mathrm{ha}$ \\
Technosphere * (input) & Planting & $0.068 \mathrm{ha}$ \\
& Mowing, by rotary mower & $9.33 \times 10^{-2} \mathrm{ha}$ \\
& Baling & $9.33 \times 10^{-2} \mathrm{ha}$ \\
& Dried roughage store, non-ventilated & $9.57 \times 10^{-8} \mathrm{~m}^{3}$ \\
Conveyor belt, at plant & $3.47 \times 10^{-5} \mathrm{~m}$ \\
Fodder loading, by self-loading trailer & $2.2654 \mathrm{~m}$ \\
& Maize drying & $50 \mathrm{~kg}$ \\
& Grinding & $0.97 \mathrm{th} . \mathrm{sh}$ \\
& Loading bales & $1.43 \mathrm{p}$ \\
& Agricultural machinery & $0.9 \mathrm{~kg}$ \\
& Electricity, at grid & $63.93 \mathrm{~kW} \cdot \mathrm{h}$
\end{tabular}

* Physical environment created or altered by humans.

\subsection{Allocation Method}

It is not uncommon for processes to produce more than one product, and the total environmental impacts of that system should be allocated over the various outputs. It is recommended in the 
International Standards Organization (ISO) Energy Management Standard ISO 14044 Standard that allocation can be avoided by splitting a huge and complex process into separate processes or expanding the system boundaries in order to cover the co-products [34]. If this is not possible, the ISO standards advise that the allocation method should be used to identify the environmental load of co-products. The biochar of gasification yield is approximately $10 \%$ of the feedstock mass and therefore $10 \%$ allocation was used [24].

\subsection{Sensitivity Analysis}

Six input factors were varied in the sensitivity analysis and are discussed below. The ranges of the factors were based on the author's knowledge of the various systems and assumptions regarding which parameters could experience variation in actual operations. One parameter at a time was changed and the effects were compared with the reference case.

\section{Results and Discussion}

The LCA results show the calculated total environmental impacts of different substances in midpoint categories. Results of the metal catalyst production system are shown in Table 3 . The midpoint categories are expressed in terms of a mass of a well-known reference substance which causes damages (weighted impact). For example, $1 \mathrm{~kg}$ of emitted $\mathrm{CH}_{4}$ has the same GHG effect as $7 \mathrm{~kg}$ of $\mathrm{CO}_{2}$ for the impact category "climate change". The $\mathrm{CO}_{2}$ is the reference material multiplied by the total GHG effect of all the various greenhouse gases. The same technique is used with carcinogenic materials: there may be hundreds of carcinogens emitted by a process but all are combined into the equivalent mass of $\mathrm{C}_{2} \mathrm{H}_{3} \mathrm{Cl}$ (vinyl chloride — a known carcinogen) for these overall reporting graphs.

Table 3. Characterization life cycle impact assessment (LCIA) results of metal catalyst production. Functional unit $=396 \mathrm{~kg} /$ day. CFC: chlorofluorocarbon; and TEG: triethylene glycol.

\begin{tabular}{|c|c|c|c|c|c|}
\hline Impact category & Unit & Total & $\begin{array}{c}\mathrm{NiO} \text { production } \\
(\%)\end{array}$ & $\begin{array}{c}\text { Alumina } \\
\text { production (\%) }\end{array}$ & $\begin{array}{c}\text { Mixing } \\
\text { process (\%) }\end{array}$ \\
\hline Carcinogens & $\mathrm{kg} \mathrm{C}_{2} \mathrm{H}_{3} \mathrm{Cl}_{(\mathrm{eq})}$ & $3.51 \times 10^{3}$ & 92.9 & 5.1 & 1.32 \\
\hline Non-carcinogens & $\mathrm{kg} \mathrm{C}_{2} \mathrm{H}_{3} \mathrm{Cl}_{(\mathrm{eq})}$ & 697 & 86.4 & 13.1 & 0.449 \\
\hline Respiratory inorganics & $\operatorname{kg}$ PM2.5 (eq) & 11.7 & 93.1 & 6.27 & 0.647 \\
\hline Ionizing radiation & $\mathrm{Bq} \mathrm{C}-14_{(\mathrm{eq})}$ & $4.19 \times 10^{3}$ & 17 & 82.7 & 0.243 \\
\hline Ozone layer depletion & $\mathrm{kg} \mathrm{CFC}-11_{(\mathrm{eq})}$ & $7.15 \times 10^{-5}$ & 29.3 & 70.3 & 0.418 \\
\hline Respiratory organics & $\mathrm{kg} \mathrm{C}_{2} \mathrm{H}_{4(\mathrm{eq})}$ & 2.59 & 88.4 & 10.3 & 1.24 \\
\hline Aquatic ecotoxicity & kg TEG water & $1.37 \times 10^{6}$ & 88.7 & 10.2 & 1.11 \\
\hline Terrestrial ecotoxicity & kg TEG soil & $1.87 \times 10^{5}$ & 93.4 & 6.56 & 0.0143 \\
\hline Terrestrial acid/nutri & $\mathrm{kg} \mathrm{SO}_{2(\mathrm{eq})}$ & 167 & 91.7 & 7.67 & 0.598 \\
\hline Land occupation & $\mathrm{m}^{2}$ org.arable & 2.16 & 15.4 & 84.4 & 0.22 \\
\hline Aquatic acidification & $\mathrm{kg} \mathrm{SO}_{2(\mathrm{eq})}$ & 144 & 95.3 & 4.08 & 0.665 \\
\hline $\begin{array}{l}\text { Aquatic eutrophication } \\
\text { eutrophication }\end{array}$ & $\mathrm{kg} \mathrm{PO}_{4(\mathrm{P}-\mathrm{lim})}$ & 0.14 & 62.8 & 36.4 & 0.835 \\
\hline Global warming & $\mathrm{kg} \mathrm{CO}_{2(\mathrm{eq})}$ & $2.95 \times 10^{3}$ & 82.3 & 16.9 & 0.776 \\
\hline Non-renewable energy & MJ primary & $1.73 \times 10^{5}$ & 90.9 & 7.91 & 1.19 \\
\hline Mineral extraction & MJ surplus & $2.34 \times 10^{3}$ & 78 & 22 & 0.00821 \\
\hline
\end{tabular}




\subsection{Life Cycle Assessment of Nickel Catalyst Production}

$\mathrm{NiO}$ manufacturing processes are responsible for approximately $82 \%$ of the calculated global warming impact of the metal catalyst. This contribution mainly results from the $\mathrm{CO}_{2}$ emissions of exploring, mining, producing and transporting Ni. The combustion of natural gas, coal and oil lead to GHG emissions and are used to supply the energy of manufacture and transportation. In this study, the average $\mathrm{CO}_{2}$ emission rate was $47.2 \mathrm{~kg} \mathrm{CO} 2 \mathrm{eq} / \mathrm{kg} \mathrm{Ni}$, which is a little higher than the $\mathrm{CO}_{2}$ emission (44.8 $\mathrm{kg} \mathrm{CO} 2 \mathrm{eq} / \mathrm{kg} \mathrm{Ni}$ ) in nickel laterite processing [35]. The difference may be due to different technologies that are used for producing $\mathrm{Ni}$. In addition, per unit mass, $\mathrm{NiO}$ production consumes more energy such as natural gas and coal than $\mathrm{Al}_{2} \mathrm{O}_{3}$ production. The primary energy input of $\mathrm{NiO}$ in this study was $350 \mathrm{MJ} / \mathrm{kg}$ which is close to $370 \mathrm{MJ} / \mathrm{kg}$ estimated by Eckelman [36] for global Ni industry. The total non-renewable energy usage was $3970 \mathrm{MJ} / \mathrm{kg}$ NiO (calculated by IMPACT 2002+ Method), which is 10 times more than the primary energy input. The difference could be attributed to the use of natural gas (non-renewable) for most primary energy inputs used in the $\mathrm{NiO}$ database.

The impacts of carcinogens and non-carcinogens released from $\mathrm{NiO}$ production are four times as much as the impacts of $\mathrm{Al}_{2} \mathrm{O}_{3}$ production. These results can be attributed to higher level of toxicity and carcinogenicity in $\mathrm{NiO}$ than $\mathrm{Al}_{2} \mathrm{O}_{3}$ [37]. Respiratory inorganics are air pollutants in the form of tiny particles (PM2.5) that can affect human lungs. These pollutants are released by heavy industries and processes such as combustion, harvesting operations, and road traffic [38]. $\mathrm{Al}_{2} \mathrm{O}_{3}$ production indicates more impacts on ionizing radiation, ozone layer depletion and land occupation than $\mathrm{NiO}$ production.

The ionizing radiation impact is caused by uranium tailings from uranium mining and subsequent usage in utility electrical power nuclear reactors (U.S. National Electric Grid Average Blend) [39]. The ozone layer is damaged by various gases emitted from fossil fuels and chlorofluorocarbons (CFCs). The mining extraction phase of aluminum and $\mathrm{Ni}$ is responsible for almost the entire LCA impact portion of the metals on the remaining midpoint categories. Compared to the separate $\mathrm{NiO}$ and $\mathrm{Al}_{2} \mathrm{O}_{3}$ production processes, the procedure of mixing the two materials into the final metal catalyst has (relatively) small midpoint impacts.

\subsection{Life Cycle Assessment of Biochar Catalyst Production}

Table 4 shows the environmental impacts of biochar production. Most contributions to the global warming impact are from switchgrass production. The fertilizer ( $\mathrm{N}$ and $\mathrm{P}$ ) used for cultivating switchgrass results in increasing nitrous oxide emissions which are a major contributor of climate change [40]. Another reason for the high impact on climate change is the electricity and fuel oil used (leading to GHG emissions) in planting and transportation. For biochar production, Roberts et al. [14] estimated that the net climate change impact was $36 \mathrm{~kg} \mathrm{CO} 2 \mathrm{eq} / \mathrm{t}$ dry switchgrass. In this study, the net GHG emission was $21.6 \mathrm{~kg} \mathrm{CO} 2 \mathrm{eq} / \mathrm{t}$ dry feedstock. Both were estimated based on cultivating switchgrass with existing agricultural land (crop change) and with typical biochar production methods (slow pyrolysis and gasification). The GHG emissions stemming from converting virgin natural land to agricultural land may be much higher [41,42].

In the biochar production carcinogens impact category, gasification results in approximately $94 \%$ of the total impact. The gasification process produces many volatile organic compounds that contribute to respiratory organics impact. In addition, because production of an industrial scale gasifier is included 
in the gasification process, non-renewable energy such as natural gas is consumed and more carcinogens are generated. The impact on respiratory inorganics of gasification process is a little higher than the same impact of switchgrass production for the same functional unit. The sources of respiratory inorganics for the gasification processes are from natural gas and coal based electricity generation. Fertilizer for switchgrass production also has an impact on respiratory inorganics. The land use and transformation of pasture and meadow in planting switchgrass are responsible for impacts of land occupation, aquatic and terrestrial ecotoxicity [43].

Table 4. Characterization LCIA results of biochar production. Functional unit $=952 \mathrm{~kg} / \mathrm{day}$.

\begin{tabular}{|c|c|c|c|c|}
\hline Impact category & Unit & Total & Switchgrass production $(\%)$ & Gasification process (\%) \\
\hline Carcinogens & $\mathrm{kg} \mathrm{C}_{2} \mathrm{H}_{3} \mathrm{Cl}_{(\mathrm{eq})}$ & 130 & 6.25 & 93.8 \\
\hline Non-carcinogens & $\mathrm{kg} \mathrm{C}_{2} \mathrm{H}_{3} \mathrm{Cl}_{(\mathrm{eq})}$ & 12.4 & 33.1 & 66.9 \\
\hline Respiratory inorganics & $\operatorname{kg~PM} 2.5_{(\mathrm{eq})}$ & 0.344 & 41.5 & 58.5 \\
\hline Ionizing radiation & $\mathrm{Bq} \mathrm{C}-14_{(\mathrm{eq})}$ & 283 & 73.5 & 26.5 \\
\hline Ozone layer depletion & $\operatorname{kg~CFC}-11_{(\mathrm{eq})}$ & $4.85 \times 10^{-6}$ & 80.7 & 19.3 \\
\hline Respiratory organics & $\mathrm{kg} \mathrm{C}_{2} \mathrm{H}_{4(\mathrm{eq})}$ & 5.6 & 1.14 & 98.9 \\
\hline Aquatic ecotoxicity & kg TEG water & $5.32 \times 10^{4}$ & 23.8 & 76.2 \\
\hline Terrestrial ecotoxicity & kg TEG soil & 4820 & 96.7 & 3.3 \\
\hline Terrestrial acid/nutri & $\mathrm{kg} \mathrm{SO}_{2(\mathrm{eq})}$ & 7.19 & 62.7 & 37.3 \\
\hline Land occupation & $\mathrm{m}^{2}$ org.arable & 8,300 & 100 & $5.84 \times 10^{-4}$ \\
\hline Aquatic acidification & $\mathrm{kg} \mathrm{SO}_{2(\mathrm{eq})}$ & 3.67 & 31 & 69 \\
\hline Aquatic eutrophication & $\mathrm{kg} \mathrm{PO}_{4(\mathrm{P}-\mathrm{lim})}$ & $8.89 \times 10^{-3}$ & 59.3 & 40.7 \\
\hline Global warming & $\mathrm{kgCO}_{2(\mathrm{eq})}$ & 206 & 69.3 & 30.7 \\
\hline Non-renewable energy & MJ primary & 7,550 & 27.6 & 72.4 \\
\hline Mineral extraction & MJ surplus & 2.7 & 70.8 & 29.2 \\
\hline
\end{tabular}

The energy used for producing switchgrass in this study is $2.19 \mathrm{MJ} / \mathrm{kg}$ which is a little higher than $1.67 \mathrm{MJ} / \mathrm{kg}$ estimated by Clarens et al. [44]. However, this result is consistent with other published values that range from $1.67 \mathrm{MJ} / \mathrm{kg}$ to $2.31 \mathrm{MJ} / \mathrm{kg}$ [45]. The energy used in a biochar production was approximately $888 \mathrm{MJ} / \mathrm{t}$ dry feedstock [14], which is a little higher than the energy used ( $793 \mathrm{MJ} / \mathrm{t}$ dry feedstock) for biochar production in this study. The reason for this difference could be disposal processes such as composting that were included in the reference study. The aquatic eutrophication impact of switchgrass production is $5.53 \times 10^{-6} \mathrm{~kg} \mathrm{PO}_{4} \mathrm{eq} / \mathrm{kg}$ that is much lower as compared to $3.5 \times 10^{-4} \mathrm{~kg} \mathrm{PO}_{4} \mathrm{eq} / \mathrm{kg}$ [44]. The yields of switchgrass in the reference article and this study were $10 \mathrm{t} / \mathrm{ha}$ and $14.8 \mathrm{t} / \mathrm{ha}$, respectively. The difference in yields of switchgrass may cause different land occupation impacts which are related to aquatic eutrophication impact. The single point ("Pt") score as seen in Figure 4 indicates that land occupation, carcinogens, non-renewable and respiratory inorganics are the most relevant of the potential environmental impacts for biochar production. The "Pt" scoring method is a relative indicator based on the European Eco-Indicator methodology of LCA impact scoring [28]. One point (1 Pt) is one thousandth of the yearly environmental load for a European. While this study is for the United States the "Pt" eco indicator system will give relative results that allow ranking of the impacts. 


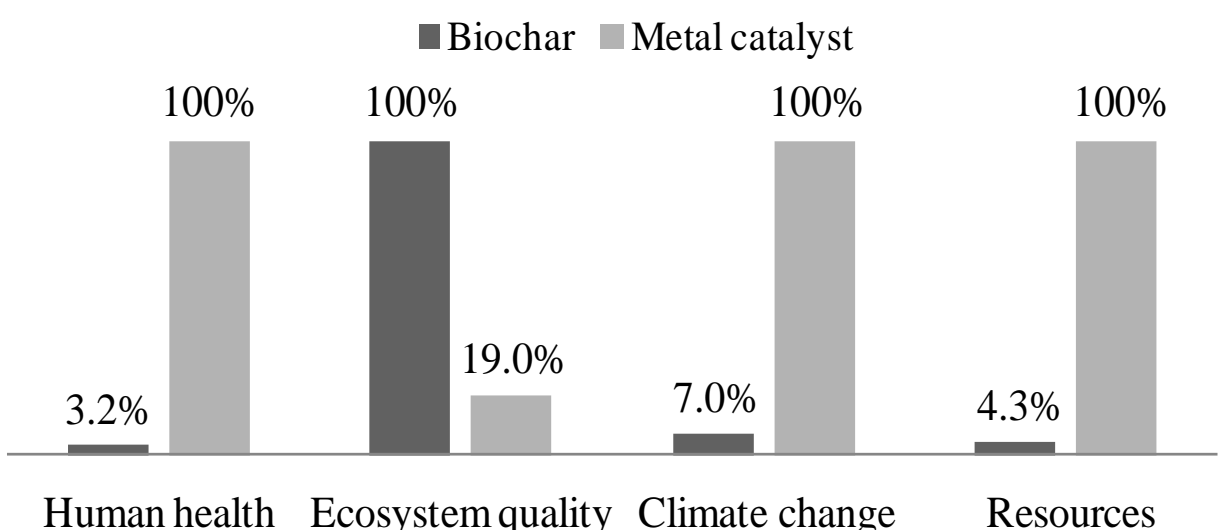

Figure 4. Comparison of damage assessment.

\subsection{Comparison Analysis}

As can be seen in Table 5, only the respiratory organics and land occupation impacts of biochar production are higher than the same impact areas of the metal catalyst production. The metal catalyst production results in 30 times more carcinogens than the biochar production. The potential global warming and non-renewable energy impacts of biochar production are $7 \%$ and $4.4 \%$ of the metal catalyst production, respectively. Part of the lesser GHG emissions of biochar production is due to soil organic carbon sequestration by switchgrass production [46]. The percentages in Figure 4 are the proportions of lower value to higher value in different impact categories, and scaling up the higher value to $100 \%$ for ease of side-by-side comparison.

Table 5. Characterized LCA comparison results (total value in each impact categories).

\begin{tabular}{cccc}
\hline Impact category & Unit & Metal catalyst (396 kg) & Biochar catalyst (953 kg) \\
\hline Carcinogens & $\mathrm{kg} \mathrm{C}_{2} \mathrm{H}_{3} \mathrm{Cl}_{(\mathrm{eq})}$ & $3.51 \times 10^{3}$ & 130 \\
Non-carcinogens & $\mathrm{kg} \mathrm{C}_{2} \mathrm{H}_{3} \mathrm{Cl}_{(\mathrm{eq})}$ & 697 & 12.4 \\
Respiratory inorganics & $\mathrm{kg} \mathrm{PM} 2.5_{(\mathrm{eq})}$ & 11.7 & 0.344 \\
Ionizing radiation & ${\mathrm{Bq} \mathrm{C}-14_{(\mathrm{eq})}}$ & $4.19 \times 10^{3}$ & 283 \\
Ozone layer depletion & $\mathrm{kg} \mathrm{CFC}-11_{(\mathrm{eq})}$ & $7.15 \times 10^{-5}$ & $4.85 \times 10^{-6}$ \\
Respiratory organics & $\mathrm{kg} \mathrm{C}_{2} \mathrm{H}_{4(\mathrm{eq})}$ & 2.59 & 5.6 \\
Aquatic ecotoxicity & $\mathrm{kg} \mathrm{TEG} \mathrm{water}$ & $1.37 \times 10^{6}$ & $5.32 \times 10^{4}$ \\
Terrestrial ecotoxicity & $\mathrm{kg} \mathrm{TEG} \mathrm{soil}$ & $1.87 \times 10^{5}$ & 4,820 \\
Terrestrial acid/nutri & $\mathrm{kg} \mathrm{SO}_{2(\mathrm{eq})}$ & 167 & 7.19 \\
Land occupation & $\mathrm{m}^{2}$ org.arable & 2.16 & 8300 \\
Aquatic acidification & $\mathrm{kg} \mathrm{SO}_{2(\mathrm{eq})}$ & 144 & 3.67 \\
Aquatic eutrophication & $\mathrm{kg} \mathrm{PO}_{4(\mathrm{P}-\mathrm{lim})}$ & 0.14 & $8.89 \times 10^{-3}$ \\
Global warming & $\mathrm{kg} \mathrm{CO}_{2(\mathrm{eq})}$ & $2.95 \times 10^{3}$ & 206 \\
Non-renewable energy & $\mathrm{MJ} \mathrm{primary}$ & $1.73 \times 10^{5}$ & 7,550 \\
Mineral extraction & $\mathrm{MJ} \mathrm{surplus}$ & $2.34 \times 10^{3}$ & 2.7 \\
\hline
\end{tabular}

The environmental performance of the two catalysts is given in Figure 5. The single score (Pt) is calculated by applying a weighting factor of each impact category to normalize score of damage assessment [47]. The cumulative scores of biochar and metal catalyst production were $0.827 \mathrm{Pt}$ and 4.4 Pt, respectively. The environmental damage of the metal catalyst is mainly caused by the impacts 
on carcinogens $(31.6 \%)$, non-renewable $(26 \%)$, respiratory inorganics $(26 \%)$, global warming $(6.8 \%)$ and non-carcinogens $(6.3 \%)$ categories. The environmental damage of biochar is mostly due to the impacts on land occupation (80\%), carcinogens (6.2\%), non-renewable (6.0\%) and respiratory inorganics $(4.1 \%)$ categories. In both catalysts systems, the impacts on ionizing radiation, ozone layer depletion, respiratory organics, aquatic ecotoxicity, terrestrial acidification/nutrition and mineral extraction categories are relatively much lower than impacts on other categories. The normalization factors of aquatic acidification and aquatic eutrophication are not well-developed in the IMPACT 2002+ method so these do not have relative scores [27].

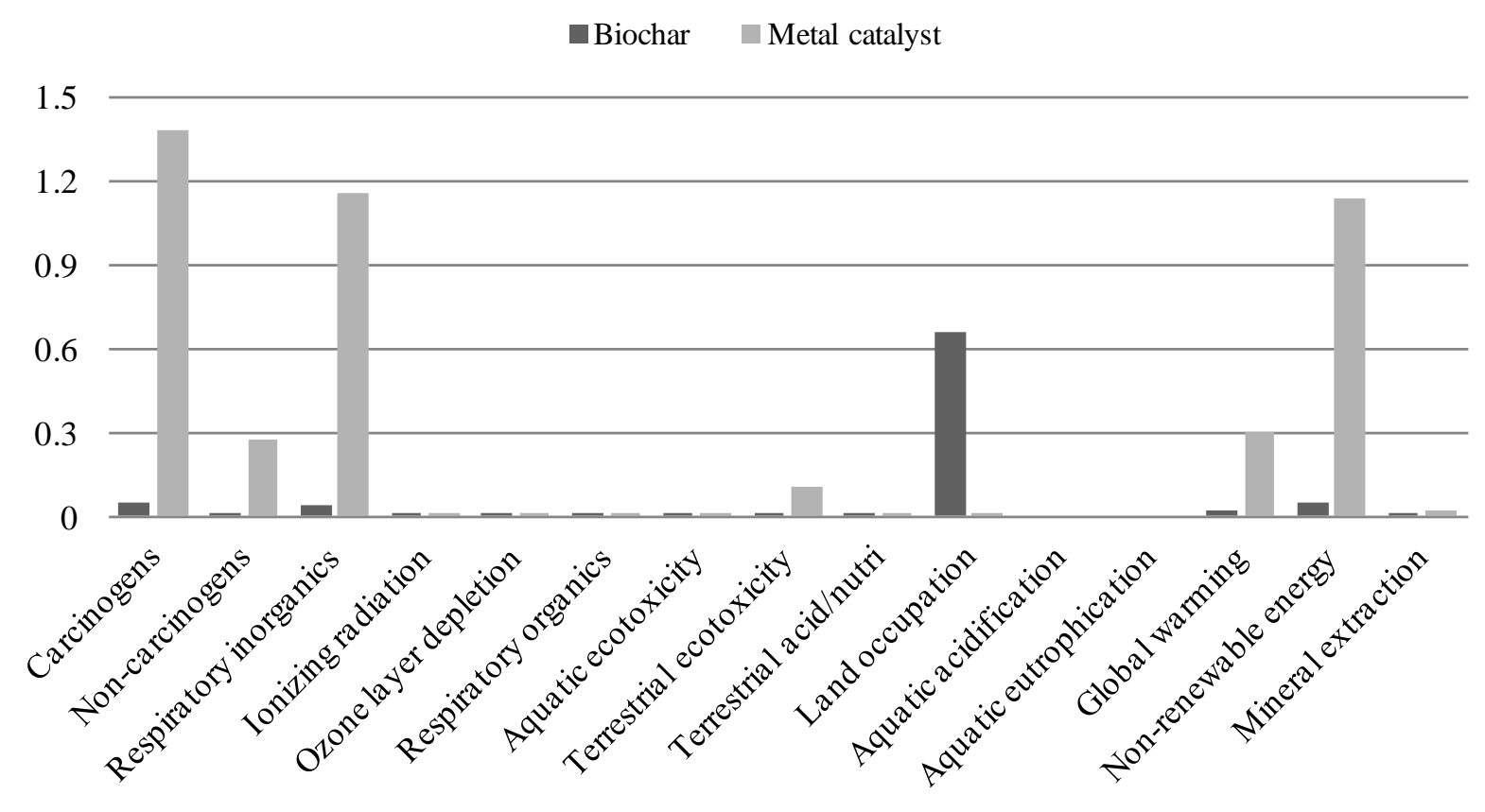

Figure 5. Comparison of LCA results expressed as single scores $(\mathrm{Pt})$.

Table 5 indicates the impact categories of the two systems. The metal catalyst production had more impacts on human health than biochar production because of its carcinogens and non-carcinogens impacts. The energy used for biochar catalyst production is roughly $4.3 \%$ of energy used in metal catalyst. The total GHG of biochar catalyst is $206 \mathrm{~kg} \mathrm{CO}_{2} \mathrm{eq}$, which is $7 \%$ of the GHG of metal catalyst production.

Compared to LCA of biochar production through slow pyrolysis of switchgrass in another study, which showed a net reduction in overall $\mathrm{CO}_{2} \mathrm{eq} / \mathrm{kg}$ [14], an emission rate of $0.21 \mathrm{~kg} \mathrm{CO} 2 \mathrm{eq} / \mathrm{kg}$ observed in this biochar production study indicated that biochar production does not achieve a net reduction in global warming impact. The reason is that the biochar, in this study, is used as a catalyst instead of a soil amendment, which means carbon sequestration of biochar is not considered. Biochar can contribute to a reduction in GHG emissions by $2.6-16 \mathrm{~kg} \mathrm{CO} 2 \mathrm{eq} / \mathrm{kg}$ when applied to soil [48]. The GHG emission of biochar produced by slow pyrolysis using microalgae was $0.4-0.66 \mathrm{~kg} \mathrm{CO} 2 \mathrm{eq} / \mathrm{kg}$ [48] that is higher than the emissions estimated in this study. This higher emission could be due to additional energy used in microalgae cultivation.

Although the climate change and resource impacts of biochar production are lower than those of metal catalyst, the biochar production indicates more (five times higher) impact on ecosystem quality. Ecosystem quality is related to land occupation (transformation), aquatic ecotoxicity and terrestrial ecotoxicity impacts. As more land is transformed from meadow and pasture to arable crop fields by human 
managements such as tillage and pest control, these are reported as adverse impacts on the ecosystem. Mining operations also occupy land areas, but need smaller area in comparison to the area needed for agricultural crop operations to grow dedicated switchgrass. Switchgrass production reduces flora and fauna diversity of the environment by changing to a monoculture system affecting the ecosystem quality (LCA scoring) [49].

\subsection{Sensitivity Analysis Results}

LCA studies are highly dependent on the accuracy of the input parameters - some of which may be educated assumptions. For this reason it is very important to test sensitivity of the model to some of these input parameters and assumptions. Wide swings in LCA output results as a result of varying the specific inputs indicate that these inputs should be scrutinized very closely. The input parameters (below) for this sensitivity analysis were selected based on domain knowledge of the processes.

\subsubsection{Vary Fraction of Nickel Oxide}

$\mathrm{NiO}$ is widely used as a catalyst in steam reforming and syngas production processes. This study uses a typical mix of $10 \mathrm{wt} \% \mathrm{NiO}$ and $90 \mathrm{wt} \% \mathrm{Al}_{2} \mathrm{O}_{3}$ as a basic mass fraction of the $\mathrm{NiO}$ catalyst. For sensitivity analysis, the mass fraction of $\mathrm{NiO}$ in the metal catalyst was adjusted to $5 \mathrm{wt} \%, 10 \mathrm{wt} \%$ and $20 \mathrm{wt} \%$ fraction of total mass for the sensitivity analysis.

As can be seen in Figure 6, by changing the weight fraction of $\mathrm{NiO}$ (5\% to 20\%) most impact categories increased by $61 \%-92 \%$.

$\square \mathrm{wt} \%$ nickel oxide $\square 20 \mathrm{wt} \%$ nickel oxide

Carcinogens
Non-carcinogens
Respiratory inorganics
Ionizing radiation
Ozone layer depletion
Respiratory organics
Aquatic ecotoxicity
Terrestrial ecotoxicity
Terrestrial acid/nutri
Land occupation
Aquatic acidification
Aquatic eutrophication
Global warming
Non-renewable energy
Mineral extraction

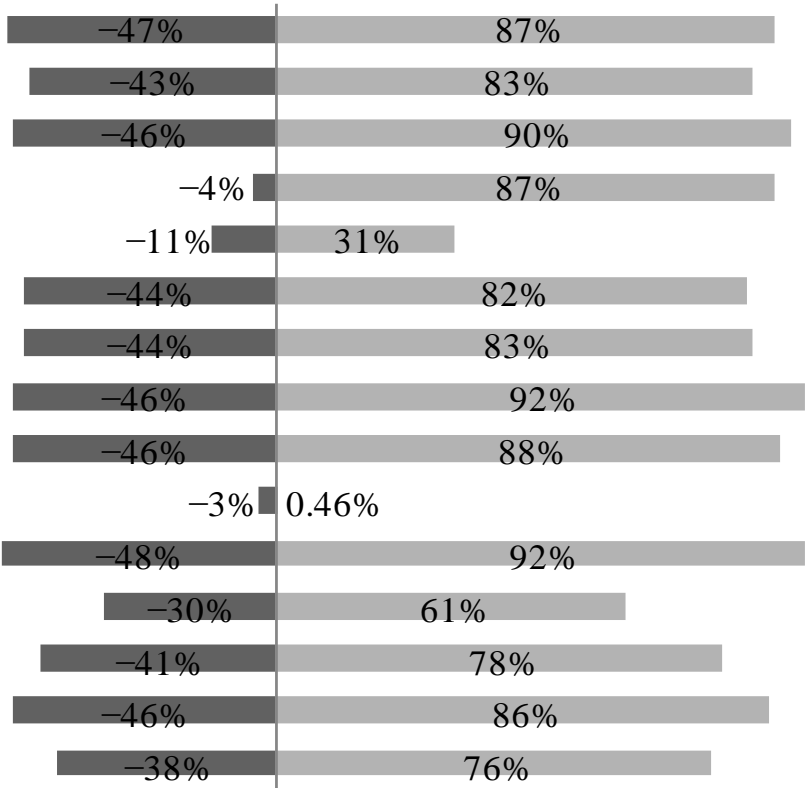

Figure 6. Impacts of $\mathrm{NiO}$ fraction in the metal catalyst.

The ionizing radiation impact increased by $87 \%$ for the $20 \%$ increase in fraction of $\mathrm{NiO}$, while it decreased by $4 \%$ for the $5 \%$ increase in $\mathrm{NiO}$. This large variation in output indicates that the percentage of $\mathrm{NiO}$ has a large influence on ionizing radiation impacts reported. The ozone layer 
depletion impact did not change as much as other impact categories. The land occupation impact was not influenced to a large degree by the $\mathrm{NiO}$ fraction. $\mathrm{Al}_{2} \mathrm{O}_{3}$ had more adverse effects than $\mathrm{NiO}$ on the ozone layer depletion and land occupation impacts. For process improvement, the LCA indicates that the amount of $\mathrm{NiO}$ in the catalyst manufacturing process must be minimized to achieve high production efficiency and low environmental impacts of the metal catalyst.

\subsubsection{Vary Energy Used in Nickel Oxide Production}

To further test the sensitivity of parameter inputs of the metal catalyst, the energy to produce the $\mathrm{NiO}$ was varied. According to the various amounts of energy used in different industrial scale manufacture of $\mathrm{NiO}$ with different technologies, the primary energy was varied to observe the effect on the LCA outputs. A symmetrical sensitivity result is shown in the Figure 7 . The $50 \%$ decrease and increase in energy used in the $\mathrm{NiO}$ production resulted in the same variation in either direction of all impact categories. The energy used in the $\mathrm{NiO}$ has more influence (positive or negative) on the carcinogens, respiratory organics and non-renewable energy than other categories. The energy adjustment minimally changes the impacts on terrestrial ecotoxicity and mineral extraction which are directly affected by land use and mining process.

\section{$\square 50 \%$ energy decrease $\square 50 \%$ energy increase}

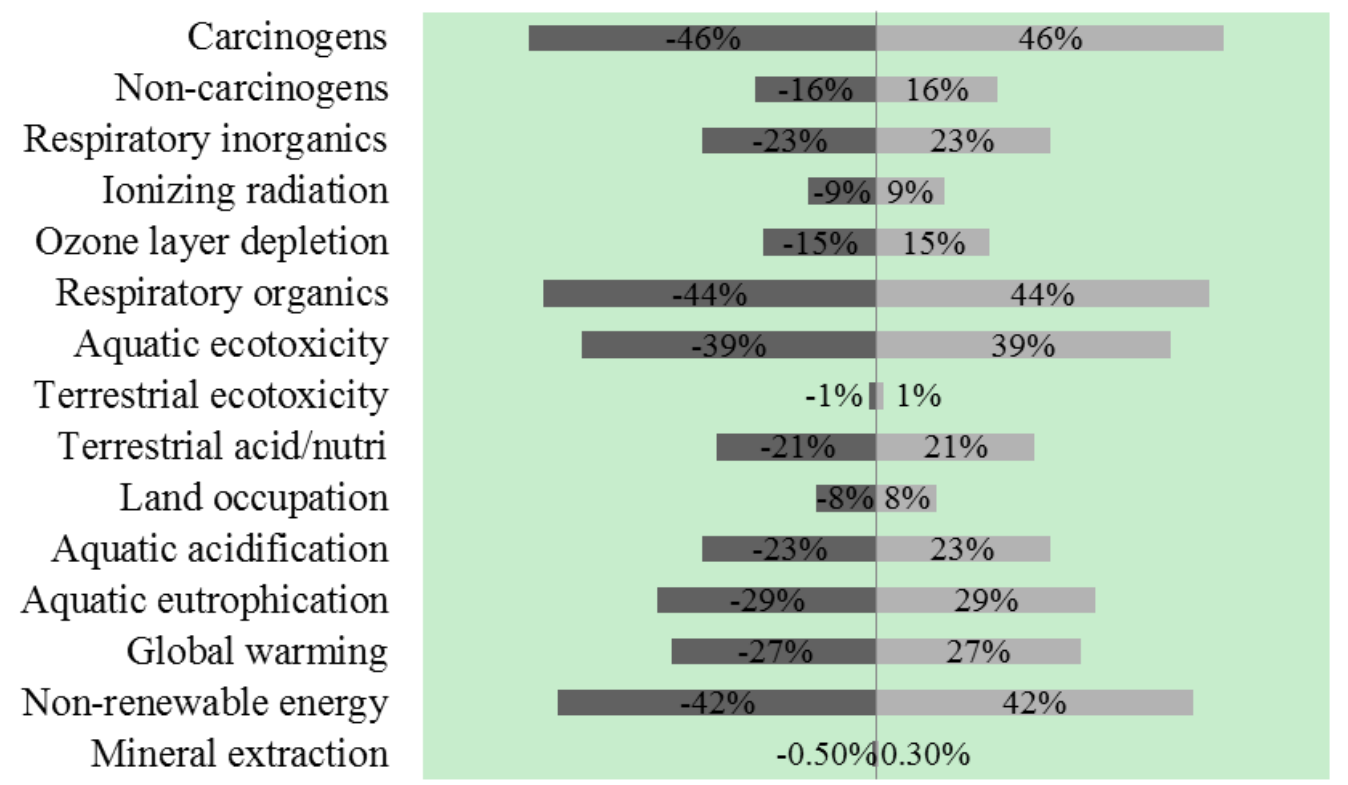

Figure 7. Energy used adjustment in $\mathrm{NiO}$ production.

\subsubsection{Vary Land Use for Switchgrass Production}

Figure 8 shows large changes in the various environmental impacts based on both land occupation and terrestrial ecotoxicity. Increasing land use by $50 \%$ leads to increase in its environmental impact because of potential damage to soil, flora and fauna, and microorganisms underground. The change in land use also determines the amount of pesticide and fertilizer used which can contribute to the impacts of terrestrial ecotoxicity. In contrast, the carcinogens and respiratory organics are relatively insensitive to the change in the land use. 


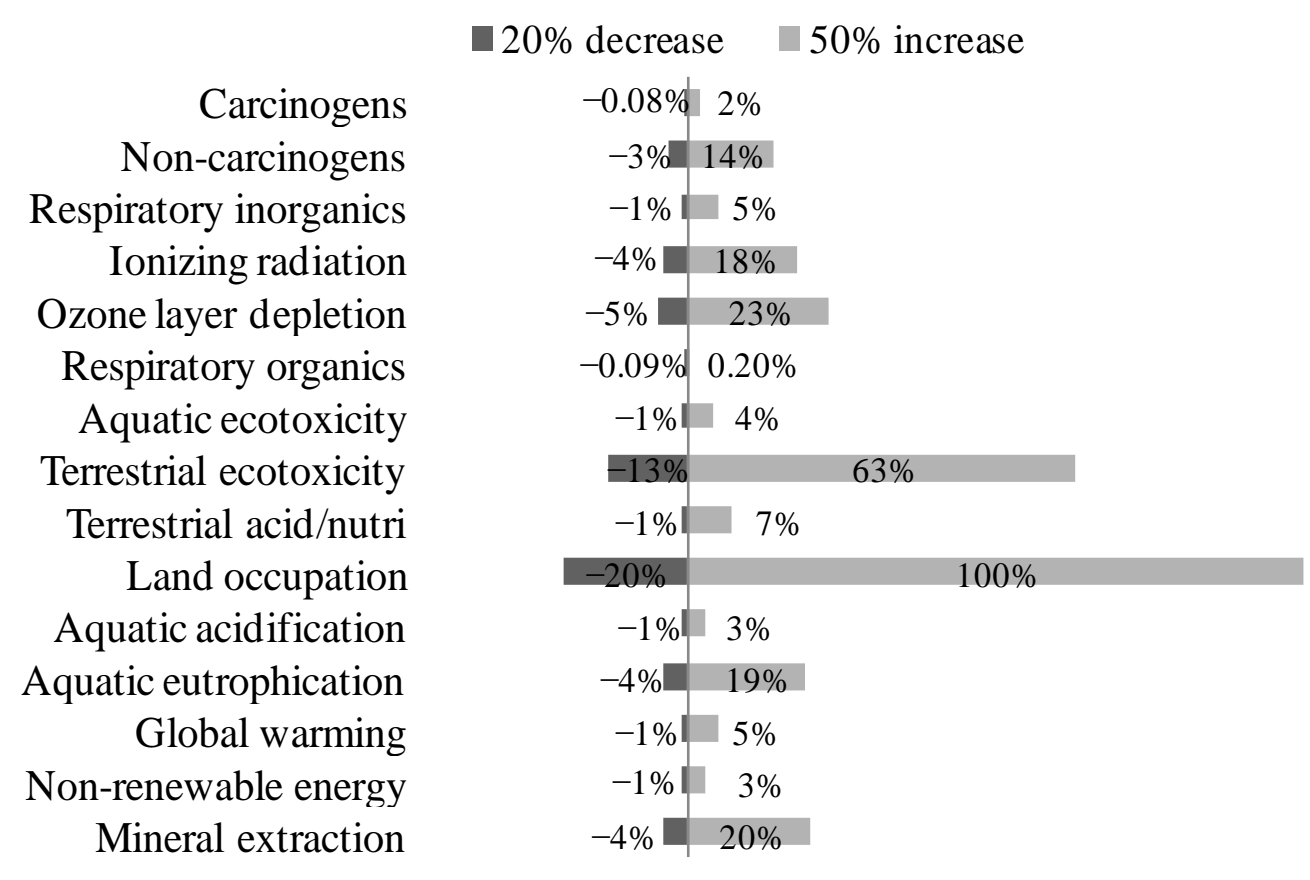

Figure 8. Land use adjustment in switchgrass.

Generally the ecosystem quality impact category is one of the few potential weakness areas of biochar production compared to the metal catalyst production, and land used should be considered as an indicator when making a sustainability decision about biomass related processes including planting switchgrass.

\subsubsection{Vary Switchgrass Yield}

Switchgrass crop yield varies with weather, soil quality and variety. The switchgrass database used in this study shows a national average yield of $14,800 \mathrm{~kg} / \mathrm{ha}$ and the specific switchgrass used can be classified as a midrange type. The other two switchgrass types in the northern and southern range have an average yield of $9867 \mathrm{~kg} / \mathrm{ha}$ and $19,733 \mathrm{~kg} / \mathrm{ha}$, respectively (Figure 9).

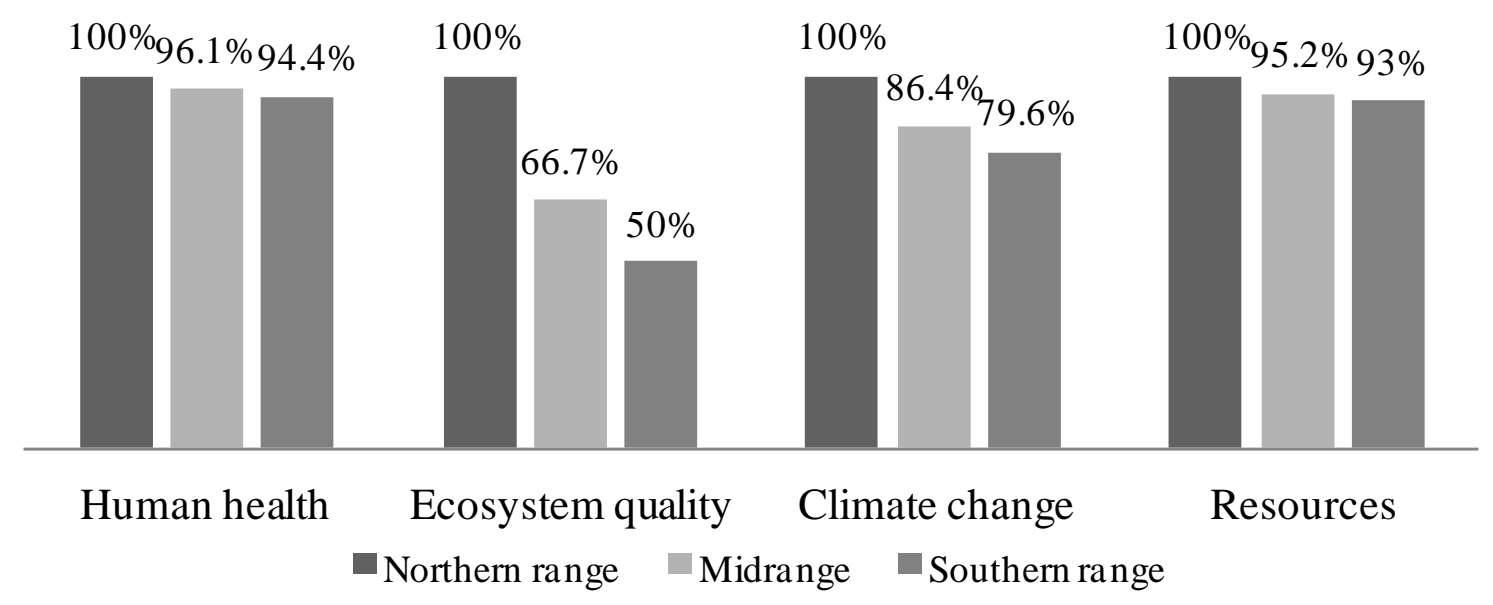

Figure 9. Damage assessment of producing syngas with various yields of switchgrass.

As the land occupation impact has a direct influence on the ecosystem quality, higher switchgrass yield biomass requires lesser land area and hence has lower influence on ecosystem quality. The 
variation on the human health and resources are relatively small, and these result from the energy used in both production and gasification of switchgrass. The variation in the climate change category is mainly due to the nitrogen fertilizer used in the switchgrass. Hence, the biomass with higher yield has lesser impact on the GHG emissions.

\subsubsection{Vary Gasification Equivalence Ratio}

Many process conditions can be controlled to optimize the syngas production efficiency. In this study, the variations in biomass moisture content (MC) and equivalence ratio (ER) were investigated to evaluate the LCA results (as shown in Table 6). The ER (ratio of air supplied to the air required for complete combustion) is an essential gasification parameter and usually modulated within a certain range in order to achieve the optimum syngas production. The ER varied from 0.2 to 0.45 associated with airflow and feedstock rate.

Table 6. Variations in inputs for producing $1 \mathrm{~m}^{3}$ syngas (adapted with modification from [29]).

ER: equivalence ratio.

\begin{tabular}{cccccc}
\hline \multirow{2}{*}{ Inputs } & \multicolumn{5}{c}{ ER } \\
\cline { 2 - 6 } & $\mathbf{0 . 2 0}$ & $\mathbf{0 . 2 9}$ & $\mathbf{0 . 3 2}$ & $\mathbf{0 . 4 0}$ & $\mathbf{0 . 4 5}$ \\
\hline Air (kg) & 0.96 & 0.95 & 0.956 & 1 & 1.08 \\
Biomass energy (MJ) & 15.7 & 11 & 9.45 & 8.56 & 7.53 \\
Biomass mass (kg) & 0.83 & 0.59 & 0.5 & 0.45 & 0.4 \\
\hline
\end{tabular}

The results in Figure 10 show that the highest damage impact occurs at the lowest ER and the variations in all damage categories are similar. The damage impact can vary from $48 \%$ to $71 \%$ of the basic value at ER of 0.2 . The variations are simply caused by the amount of biomass and energy used. The biomass and energy used at an ER of 0.2 are two times than those at ER of 0.45 hence increasing the damage impacts by a factor of 2 .

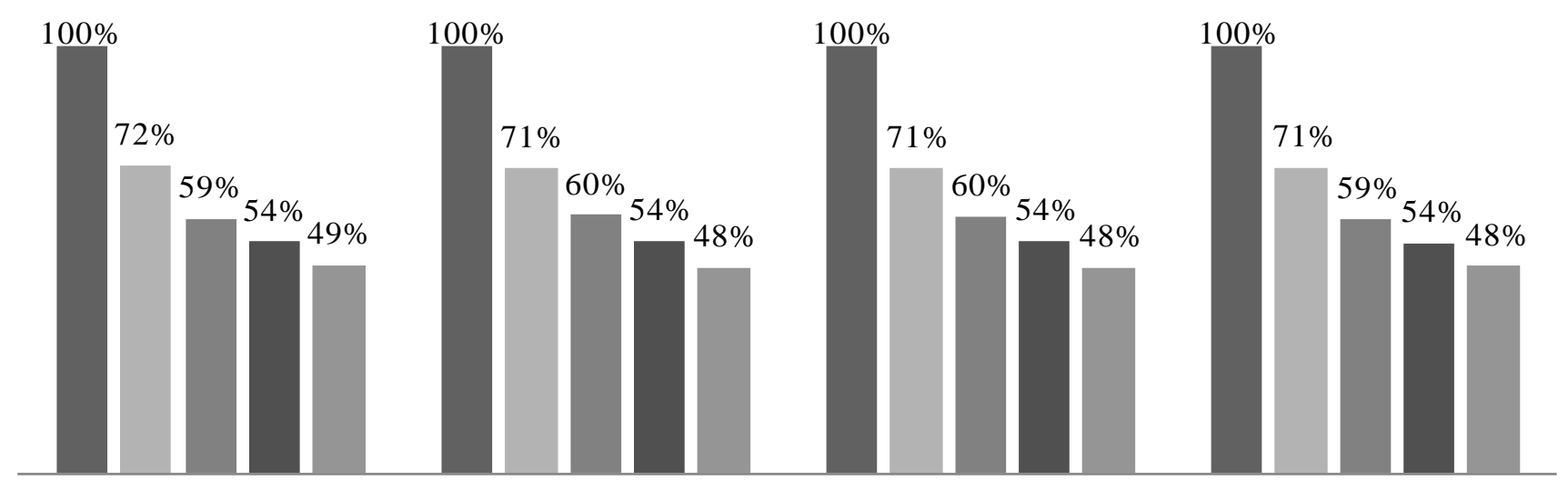

Human health

$$
\text { Ecosystem quality }
$$

Climate change

Resources

$\mathrm{ER}=0.2 \square \mathrm{ER}=0.29 \square \mathrm{ER}=0.32 \square \mathrm{ER}=0.4 \square \mathrm{ER}=0.45$

Figure 10. Damage assessment of producing syngas with various ERs. 


\subsubsection{Vary Biomass Moisture Content Fed to the Gasifier}

The MC of the gasification feedstock was suspected to have a large effect on variability of the LCA output due to the latent heat of vaporization (enthalpy) of water in the feedstock required and the resulting effect on gasification operation efficiency. Typically the biomass MC is suggested at 10\%-20\% on wet basis weight [49]. High MC will reduce the reaction temperature and may produce syngas gas with lower yield and efficiency [49]. Based on the study data, three MC levels of 9\%, 19\% and 29\% were chosen (Table 7).

Table 7. Gasification products at various levels of switchgrass moisture content (MC) (adapted with modification from [49]).

\begin{tabular}{cccccccc}
\hline \multirow{2}{*}{ MC (\% wet basis) } & \multicolumn{7}{c}{ Gasification products (\% feed weight) } \\
\cline { 2 - 8 } & $\mathbf{H}_{\mathbf{2}}$ & $\mathbf{C O}$ & $\mathbf{C H}_{\mathbf{4}}$ & $\mathbf{C O}_{\mathbf{2}}$ & $\mathbf{H}_{\mathbf{2}} \mathbf{O}$ & $\mathbf{T a r}$ & Ash \\
\hline 9 & 0.90 & 37.91 & 5.74 & 55.92 & 17.71 & 2.81 & 8.94 \\
19 & 0.59 & 34.54 & 4.62 & 51.07 & 20.26 & 2.14 & 8.47 \\
29 & 0.43 & 29.42 & 3.41 & 50.01 & 21.06 & 1.62 & 8.28 \\
\hline
\end{tabular}

As shown in Figure 11, the highest variation occurs in the climate change category with an increase of $120 \%-240 \%$ with increase in MC from $9 \%$ to $29 \%$. This difference in the climate change is due to supplemental heat required to gasify additional $\mathrm{MC}$ in the switchgrass. For instance, the climate change impact of $19 \% \mathrm{MC}$ is $65 \%$ than that of $29 \% \mathrm{MC}$. The ecosystem quality does not change significantly because of small variations in the MC. The human health and (energy) resources categories are also affected by MC and high(er) heating value (HHV) of the syngas.

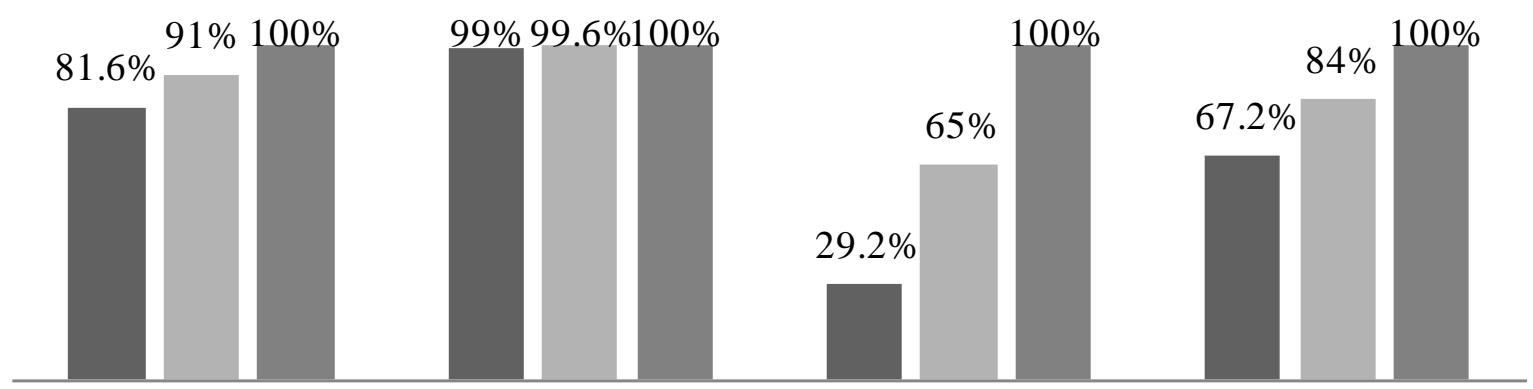

Human health Ecosystem quality Climate change Resources

$\square 9 \% \mathrm{MC} \square 19 \% \mathrm{MC} \square 29 \% \mathrm{MC}$

Figure 11. Damage assessment of producing syngas with various levels of switchgrass MC.

\section{Conclusions}

A comparative LCA was applied to model the environmental impact of producing metal versus biochar as a catalyst used in the syngas cleaning system. The LCA results showed that production of biochar requires $95.7 \%$ less energy than production of the metal catalyst which is a mixture of $\mathrm{NiO}$ and $\mathrm{Al}_{2} \mathrm{O}_{3}$. Producing biochar as a catalyst has a potential in reducing 93\% GHG emissions as compared to producing a metal catalyst. Although biochar production system has more potential impacts on ecosystem quality due to land use, it has lesser negative impacts on human health than 
metal catalyst production. If biochar is examined as a waste of gasification, its ecological impacts will be even less.

Most processes of the metal catalyst manufacture could be optimized to reduce the waste materials, energy and correspondingly the environmental impacts to some degree. The impact of biochar production can be improved by mitigating land occupation such as growing a higher yield switchgrass in the southern range. Growing switchgrass on marginal lands with no fertilizer would also lower impacts but would also probably lower harvest yields. The impacts of the gasification process in general can be improved by optimizing reaction conditions and reactor design for use of low energy and materials. In all, the sustainability of biochar catalysts appears promising when compared to conventional transition metal catalysts using this preliminary LCA.

Future research should include the comparison of biochar catalyst to other non-metal catalyst possibilities such as activated carbon. The use of syngas to generate electrical power and fuels at a distributed location as well as recycling and disposal of the catalysts should also be examined.

\section{Acknowledgments}

Authors acknowledge the support of South Central Sun Grant Program and Oklahoma Agricultural Experiment Station for this study.

\section{Author Contributions}

All three authors significantly contributed to the scientific study and writing. Robert S. Frazier supervised Enze Jin to conduct life cycle analysis, interpretation of results and writing. Ajay Kumar provided technical information on biochar and contributed to the interpretation of results.

\section{Conflicts of Interest}

The authors declare no conflict of interest.

\section{References}

1. Caputo, A.C.; Palumbo, M.; Pelagagge, P.M.; Scacchia, F. Economics of biomass energy utilization in combustion and gasification plants: Effects of logistic variables. Biomass Bioenergy 2005, 28, 35-51.

2. Demirbas, A. Biofuels sources, biofuel policy, biofuel economy and global biofuel projections. Energy Convers. Manag. 2008, 49, 2106-2116.

3. Alauddin, Z.A.B.Z.; Lahijani, P.; Mohammadi, M.; Mohamed, A.R. Gasification of lignocellulosic biomass in fluidized beds for renewable energy development: A review. Renew. Sustain. Energy Rev. 2010, 14, 2852-2862.

4. Pereira, E.G.; da Silva, J.N.; de Oliveira, J.L.; Machado, C.S. Sustainable energy: A review of gasification technologies. Renew. Sustain. Energy Rev. 2012, 16, 4753-4762.

5. Corti, A.; Lombardi, L. Biomass integrated gasification combined cycle with reduced $\mathrm{CO}_{2}$ emissions: Performance analysis and life cycle assessment (LCA). Energy 2004, 29, 2109-2124. 
6. Koroneos, C.; Dompros, A.; Roumbas, G. Hydrogen production via biomass gasification-A life cycle assessment approach. Chem. Eng. Process. Process Intensif. 2008, 47, 1261-1268.

7. Gerber, M.A. Review of Novel Catalysts for Biomass Tar Cracking and Methane Reforming; Pacific Northwest National Laboratory: Richland, WA, USA, 2007.

8. Mani, S.; Kastner, J. Catalytic cracking of tar using biochar as a catalyst. In Proceedings of the 2010 ASABE Annual International Meeting, Pittsburgh, PA, USA, 20-23 June 2010.

9. Kimura, T.; Miyazawa, T.; Nishikawa, J.; Kado, S.; Okumura, K.; Miyao, T.; Naito, S.; Kunimori, K.; Tomishige, K. Development of Ni catalysts for tar removal by steam gasification of biomass. Appl. Catal. B Environ. 2006, 68, 160-170.

10. Abu El-Rub, Z.; Bramer, E.A.; Brem, G. Experimental comparison of biomass chars with other catalysts for tar reduction. Fuel 2008, 87, 2243-2252.

11. Sohi, S.; Krull, E.; Lopez-Capel, E.; Bol, R. A review of biochar and its use and function in soil. Adv. Agron. 2010, 105, 47-82.

12. Woolf, D.; Amonette, J.E.; Street-Perrott, F.A.; Lehmann, J.; Joseph, S. Sustainable biochar to mitigate global climate change. Nat. Commun. 2010, 1, doi:10.1038/ncomms1053.

13. Schahczenski, J. Biochar and Sustainable Agriculture; ATTRA-National Sustainable Agriculture Information Service: Butte, MT, USA, 2010.

14. Roberts, K.G.; Gloy, B.A.; Joseph, S.; Scott, N.R.; Lehmann, J. Life cycle assessment of biochar systems: Estimating the energetic, economic, and climate change potential. Environ. Sci. Technol. 2009, 44, 827-833.

15. Huang, Y.-F.; Syu, F.-S.; Chiueh, P.-T.; Lo, S.-L. Life cycle assessment of biochar cofiring with coal. Bioresour. Technol. 2013, 131, 166-171.

16. Sparrevik, M.; Field, J.L.; Martinsen, V.; Breedveld, G.D.; Cornelissen, G. Life cycle assessment to evaluate the environmental impact of biochar implementation in conservation agriculture in Zambia. Environ. Sci. Technol. 2013, 47, 1206-1215.

17. Bojacá, C.R.; Schrevens, E. Parameter uncertainty in LCA: Stochastic sampling under correlation. Int. J. Life Cycle Assess. 2010, 15, 238-246.

18. Vigon, B.W.; Jensen, A.A. Life cycle assessment: Data quality and databases practitioner survey. J. Clean. Prod. 1995, 3, 135-141.

19. Huijbregts, M.A. Application of uncertainty and variability in LCA. Int. J. Life Cycle Assess. 1998, 3, 273-280.

20. Ardente, F.; Beccali, G.; Cellura, M.; Lo Brano, V. Life cycle assessment of a solar thermal collector: Sensitivity analysis, energy and environmental balances. Renew. Energy 2005, 30, 109-130.

21. Baker, J.W.; Lepech, M.D. Treatment of uncertainties in life cycle assessment. In Proceedings of the ICOSSAR 2009-10th International Conference on Structural Safety and Reliability, Osaka, Japan, 13-17 September 2009.

22. Brown, T.R.; Zhang, Y.N.; Hu, G.P.; Brown, R.C. Techno-economic analysis of biobased chemicals production via integrated catalytic processing. Biofuels Bioprod. Biorefining 2012, 6 , 73-87.

23. Marin, L.S. Treatment of Biomass-Derived Synthesis Gas Using Commercial Steam Reforming Catalysts and Biochar. Ph.D. Thesis, Oklahoma State University, Stillwater, OK, USA, 2011. 
24. Brewer, C.E.; Schmidt-Rohr, K.; Satrio, J.A.; Brown, R.C. Characterization of biochar from fast pyrolysis and gasification systems. Environ. Progress Sustain. Energy 2009, 28, 386-396.

25. Spath, P.L.; Mann, M.K.; Kerr, D.R. Life Cycle Assessment of Coal-Fired Power Production; National Renewable Energy Laboratory: Golden, CO, USA, 1999.

26. National Renewable Energy Laboratory. U.S. Life Cycle Inventory Database, 2012. Available online: https://www.lcacommons.gov/nrel/search 2012 (accessed on 19 November 2012).

27. Jolliet, O.; Margni, M.; Charles, R.; Humbert, S.; Payet, J.; Rebitzer, G.; Rosenbaum, R. IMPACT 2002+: A new life cycle impact assessment methodology. Int. J. Life Cycle Assess. 2003, 8, 324-330.

28. Bare, J.C.; Hofstetter, P.; Pennington, D.W.; de Haes, H.A.U. Midpoints versus endpoints: The sacrifices and benefits. Int. J. Life Cycle Assess. 2000, 5, 319-326.

29. Sharma, A.M.; Kumar, A.; Patil, K.N.; Huhnke, R.L. Performance evaluation of a lab-scale fluidized bed gasifier using switchgrass as feedstock. Trans. ASABE 2011, 54, 2259-2266.

30. Life Cycle Assessment of Nickel Products; Ecobalance, Inc.: Bethesda, MD, USA, 2000; pp. 1-99.

31. US-EI SimaPro Database; EarthShift, LLC: Huntington, VT, USA, 2013.

32. Kiss, E.; Bošković, G.; Lazić, M.; Lomić, G.; Marinković-Nedučin, R. The morphology of the $\mathrm{NiO}-\mathrm{Al}_{2} \mathrm{O}_{3}$ catalyst. Scanning 2006, 28, 236-241.

33. Gorokhov, V.; Manfredo, L.; Ratafia-Brown, J.; Ramezan, M.; Stiegel, G. Life cycle assessment of gasification-based power cycles. In Proceedings of the 2000 International Joint Power Generation Conference, Miami Beach, FL, USA, 23-26 July 2000.

34. Goedkoop, M.; de Schryver, A.; Oele, M.; Durksz, S.; de Roest, D. Introduction to LCA with SimaPro 7; PRé Consultants: Amersfoort, The Netherlands, 2008.

35. Norgate, T.; Jahanshahi, S. Assessing the energy and greenhouse gas footprints of nickel laterite processing. Miner. Eng. 2011, 24, 698-707.

36. Eckelman, M.J. Facility-level energy and greenhouse gas life-cycle assessment of the global nickel industry. Resour. Conserv. Recycl. 2010, 54, 256-266.

37. Coogan, T.P.; Latta, D.M.; Snow, E.T.; Costa, M.; Lawrence, A. Toxicity and carcinogenicity of nickel compounds. CRC Crit. Rev. Toxicol. 1989, 19, 341-384.

38. Weisbrod, A.V.; van Hoof, G. LCA-measured environmental improvements in Pampers ${ }^{\circledR}$ diapers. Int. J. Life Cycle Assess. 2012, 17, 145-153.

39. Frischknecht, R.; Braunschweig, A.; Hofstetter, P.; Suter, P. Human health damages due to ionising radiation in life cycle impact assessment. Environ. Impact Assess. Rev. 2000, 20, 159-189.

40. Bai, Y.; Luo, L.; van der Voet, E. Life cycle assessment of switchgrass-derived ethanol as transport fuel. Int. J. Life Cycle Assess. 2010, 15, 468-477.

41. Fargione, J.; Hill, J.; Tilman, D.; Polasky, S.; Hawthorne, P. Land clearing and the biofuel carbon debt. Science 2008, 319, 1235-1238.

42. Searchinger, T.; Heimlich, R.; Houghton, R.A.; Dong, F.; Elobeid, A.; Fabiosa, J.; Tokgoz, S.; Hayes, D.; Yu, T.H. Use of U.S. croplands for biofuels increases greenhouse gases through emissions from land-use change. Science 2008, 319, 1238-1240.

43. Van der Voet, E. Land Use in LCA; CML-SSP Working Paper 02.002; Section Substances and Products, Centre of Environmental Science, Leiden University (CML-SSP): Leiden, The Netherlands, 2001. 
44. Clarens, A.F.; Resurreccion, E.P.; White, M.A.; Colosi, L.M. Environmental life cycle comparison of algae to other bioenergy feedstocks. Environ. Sci. Technol. 2010, 44, 1813-1819.

45. Kim, S.; Dale, B.E. Cumulative energy and global warming impact from the production of biomass for biobased products. J. Ind. Ecol. 2003, 7, 147-162.

46. Liebig, M.A.; Schmer, M.R.; Vogel, K.P.; Mitchell, R.B. Soil carbon storage by switchgrass grown for bioenergy. Bioenergy Res. 2008, 1, 215-222.

47. Humbert, S.; de Schryver, A.; Margni, M.; Jolliet, O. IMPACT 2002+: User Guide; Draft for Version Q2.21; Industrial Ecology \& Life Cycle Systems Group, GECOS, Swiss Federal Institute of Technology Lausanne (EPFL): Lausanne, Switzerland, 2005.

48. Grierson, S.; Strezov, V.; Bengtsson, J. Life cycle assessment of a microalgae biomass cultivation, bio-oil extraction and pyrolysis processing regime. Algal Res. 2013, 2, 299-311.

49. Worley, M.; Yale, J. Biomass Gasification Technology Assessment: Consolidated Report; NREL/SR-5100-57085; National Renewable Energy Laboratory (NREL): Golden, CO, USA, 2012.

(C) 2015 by the authors; licensee MDPI, Basel, Switzerland. This article is an open access article distributed under the terms and conditions of the Creative Commons Attribution license (http://creativecommons.org/licenses/by/4.0/). 